Naohiko Seki • Akiko Hayashi $\cdot$ Masumi Abe

Ryoko Araki • Akira Fujimori · Ryutaro Fukumura

Atsushi Hattori • Sumie Kozuma • Miki Ohhira

Tada-aki Hori • Toshiyuki Saito

\title{
Chromosomal assignment of the gene for human DNA-PKcs interacting protein (KIP) on chromosome 15q25.3-q26.1 by somatic hybrid analysis and fluorescence in situ hybridization
}

Received: June 18, 1998 / Accepted: July 21, 1998

\begin{abstract}
We report the chromosomal location of the gene for DNA-PKcs interacting protein KIP. Based on fluorescence in situ hybridization and polymerase chain reaction (PCR)-based analyses with both a human/rodent monochromosomal hybrid cell panel and a radiation hybrid mapping panel, this gene was mapped to q25.3-q26.1 region on chromosome 15.
\end{abstract}

Key words DNA-PKcs · KIP · Chromosome 15q25.3-q26.1 · FISH $\cdot$ Radiation hybrid mapping

DNA-dependent protein kinase (DNA-PK) has a role in the repair of double-strand DNA breaks and in the related process of $\mathrm{V}(\mathrm{D}) \mathrm{J}$ recombination during lymphoid development (Jackson and Jeggo 1995; Jeggo et al. 1995). DNA-PK is composed of a large catalytic subunit of approximately $470 \mathrm{kDa}$ (DNA-PKcs) and DNA-binding protein, Ku (Anderson and Carter 1996; Jackson 1996; Lees-Miller 1996). The catalytic subunit, DNA-PKcs, belongs to the phosphatidylinositol-3 kinase family of proteins (Hartley et al. 1995) that includes ATM (Savitsky et al. 1995), FRAP (Brown et al. 1994; Sabatini et al. 1994) and ATR (Cimprich et al. 1996; Enoch and Norbury 1995). Recently,

N. Seki $\cdot$ A. Hayashi $\cdot$ A. Hattori $\cdot$ S. Kozuma $\cdot$ T. Hori $\cdot$ T. Saito $(\square)$

Genome Research Group, National Institute of Radiological Sciences, Anagawa, 4-9-1, Inage-ku, Chiba 263-8555, Japan

Tel. 81-43-206-3135; Fax 81-43-251-9818

e-mail: t_saito@nirs.go.jp

M. Abe $\cdot$ R. Araki · A. Fujimori · R. Fukumura

Division of Biology and Oncology, National Institute of Radiological Sciences, Anagawa, Inage-ku, Chiba, Japan

M. Ohhira

Division of Biochemistry, Chiba Cancer Center Research Institute,

Nitona, Chuoh-ku, Chiba Japan a novel DNA-PKcs interacting protein, KIP (kinase interacting protein), was isolated by the use of a twohybrid analysis which showed a significant homology to calcineurin B (Wu and Lieber 1997). The possibility is discussed that the protein might regulate the phosphorylation pathway induced in DNA end joining (Wu and Lieber 1997).

Chromosomal assignment of the human KIP gene was made by polymerase chain reaction (PCR) analysis of a human/rodent somatic cell hybrid panel and a radiation hybrid panel. The PCR primer sets were designed for the $3^{\prime}$ untranslated region of the gene. The specific amplified human PCR product was detected only from the hybrid containing human chromosome 15 (Fig. 1a). We performed further mapping analysis using a radiation hybrid panel (Genebridge 4, Research Genetics, Huntsville, AL, USA) with the same primers used in the assay for the human/ rodent somatic cell hybrid panel. Statistical analysis of the radiation hybrid mapping data was carried out using the RHMAPPER software package (http://www genome. wi.mit.edu/cgi-bin/contig/rhmapper.pl). The data vector for the KIP gene was 000001010001000111000100000110 01001001000110001000110000010000001100001011000000 1010011010101 , and the consequent report indicated the gene was mapped between markers GCT14H07 and WI6947, both of which have been cytogenetically mapped to 15q25-q26. The position of the gene is $1.31 \mathrm{cR}$ distal from GCT14H07.

To confirm the PCR-based chromosome mapping by an independent approach, we performed R-banding fluorescence in situ hybridization (FISH) using the P1 phase DNA as described previously (Saito et al. 1995, 1997; Seki et al. 1997). The P1 clone was isolated by the method described previously (Ohira et al. 1997). Clear doublet signals were consistently demonstrated at the q25.3-q26.1 position of chromosome 15. The typical pattern of the FISH experiment is represented in Fig. 1b,c. Thus, the gene was judged to map on $15 \mathrm{q} 25.3-\mathrm{q} 26.1$.

Our precise chromosomal positioning data of such the gene will contribute toward ongoing positional candidate approaches for the disease genes linked to this genomic locus. 

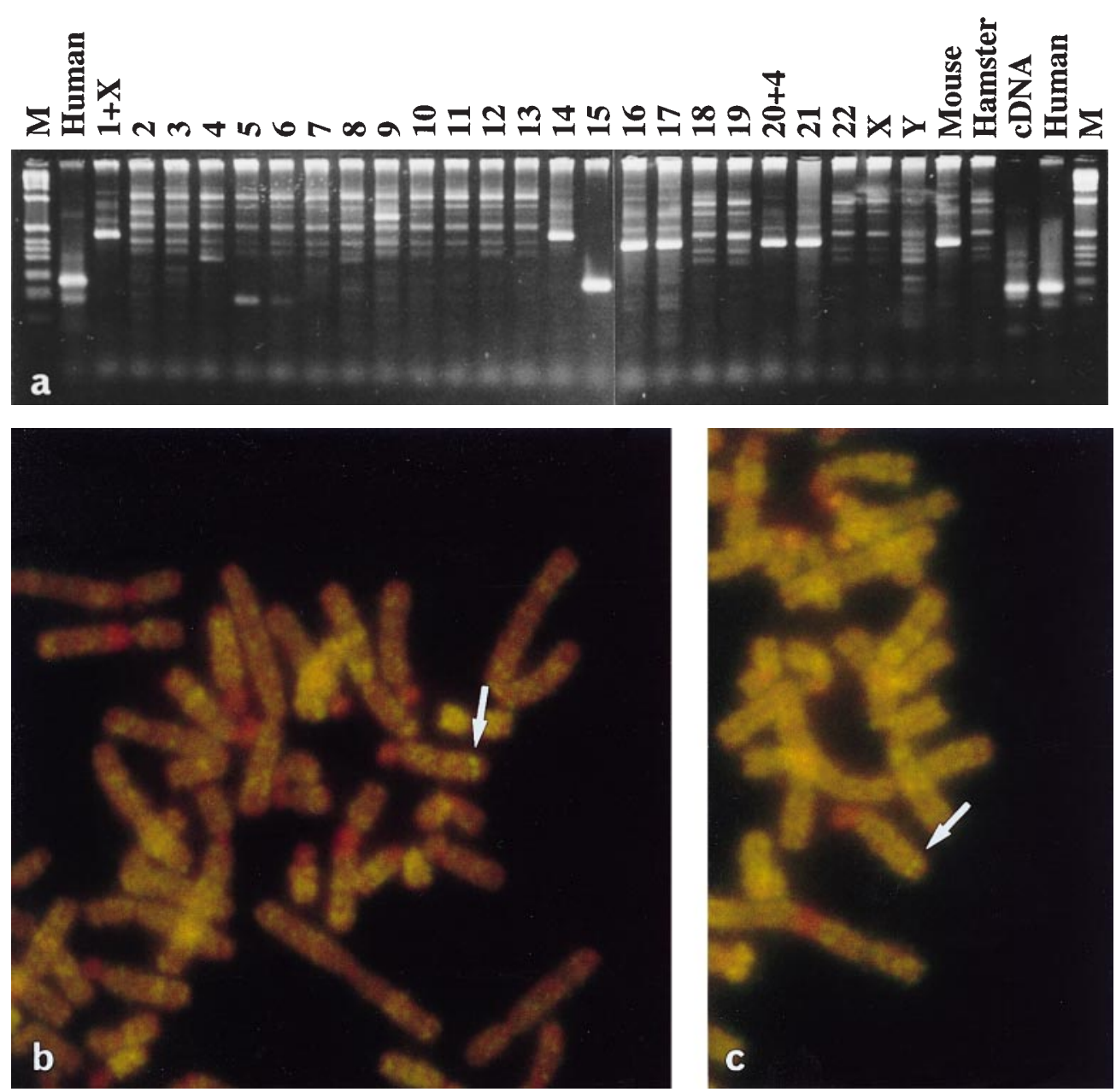

Fig. 1a-c Chromosome mapping of the KIP gene. a PCR analysis of human/rodent hybrid cell panel. A PCR screening of a human/rodent somatic cell hybrid panel was performed to map the KIP gene to human chromosome 15. DNA of the human/rodent somatic cell hybrid panel was purchased from the National Institute of General Medicine Service, Coriell Cell Repositories (Palo Alto, CA, USA). Human, mouse, and hamster genomic DNAs were also included as controls in the assay. Primers used for PCR amplification correspond to (5'TGACAGCAGCCCCAGCGTGTGTCCT-3') and (5'-GACAACAGCAGTGAGGAGAGGCCC-3') (PCR product size: 260 bp). PCR was carried out in a final volume of $10 \mu \mathrm{l}$ containing $1 \times$ LA-PCR buffer (Takara, Kyoto, Japan), $2 \mu \mathrm{M}$ of each primer, $200 \mu \mathrm{M}$ of each dNTP, 50 ng of template DNA, and 0.01 unit of LA-Taq DNA polymerase (Takara). Temperature and time profiles were 30 cycles of $95^{\circ} \mathrm{C}$ for $20 \mathrm{~s}$ and $66^{\circ} \mathrm{C}$ for $1 \mathrm{~min}$. Numbers on the top of each lane indicate the human chromosome contained in each somatic cell hybrid. b,c Fluorescence in situ hybridization (FISH) of the KIP gene. FISH was carried out using a bioinylated hybridization probe made from P1 phage clone harboring the KIP gene. Arrows indicate the hybridization signals on human chromosome 15q25.3-q26.1. The metaphase spreads were photographed with a Nikon B-2A filter.

\section{References}

Anderson CW, Carter TH (1996) The DNA-activated protein kinase - DNA-PK. Curr Top Microbiol Immunol 217: 91-111

Brown EJ, Albers MW, Shin TB, Ichikawa K, Keith CT, Lane WS, Schreiber SL (1994) A mammalian protein targeted by G1-arresting rapamycin-receptor complex. Nature 369: 756-758

Cimprich KA, Shin TB, Keith CT, Schreiber SL (1996) cDNA cloning and gene mapping of a candidate human cell cycle checkpoint protein. Proc Natl Acad Sci USA 93: 2850-2855

Enoch T, Norbury C (1995) Cellular responses to DNA damage: cellcycle checkpoints, apoptosis and the roles of p53 and ATM. Trends Biochem Sci 20: 426-430

Hartley KO, Gell D, Smith GC, Zhang H, Divecha N, Connelly MA, Admon A, Lees-Miller SP, Anderson CW, Jackson SP (1995) DNAdependent protein kinase catalytic subunit: a relative of phosphatidylinositol 3-kinase and the ataxia telangiectasia gene product. Cell 82: 849-856

Jackson SP (1996) The recognition of DNA damage. Curr Opin Genet Dev 6: 19-25

Jackson SP, Jeggo PA (1995) DNA double-strand break repair and V(D)J recombination: involvement of DNA-PK. Trends Biochem Sci 20: 412-415

Jeggo PA, Taccioli GE, Jackson SP (1995) Menage a trois: double strand break repair, V(D)J recombination and DNA-PK. Bioessays 17: 949-957

Lees-Miller SP (1996) The DNA-dependent protein kinase, DNA-PK: 10 years and no ends in sight. Biochem Cell Biol 74: 503-512

Ohhira M, Seki N, Nagase T, Suzuki E, Nomura N, Ohara O, Hattori M, Sakaki Y, Eki T, Murakami Y, Saito T, Ichikawa H, Ohki M (1997) Gene identification in 1.6-Mb region of the Down syndrome region on chromosome 21. Genome Res 7: 47-58

Sabatini DM, Erdjument-Bromage H, Lui M, Tempst P, Synder SH (1994) RAFT1: a mammalian protein that binds to FKBP12 in a 
rapamycin-dependent fashion and is homologous to yeast TORs. Cell 78: 35-43

Saito T, Seki N, Matsuda Y, Kitahara M, Murata M, Kanda N, Nomura N, Yamamoto T, Hori T (1995) Identification of the human ERK gene as a putative receptor tyrosine kinase and its chromosomal localization to 1p36.1: a comparative mapping of human mouse, and rat chromosomes, Genomics 26: 382-384

Saito T, Seki N, Ishii H, Ohhira M, Hayashi A, Kozuma S, Hori T (1997) Complementary DNA cloning and chromosomal mapping of a novel phosphatidylinositol kinase gene. DNA Res 4: 301-305
Savitsky K, Bar-Shira A, Gilad S, Rotman G, Ziv Y, Vanagaite L, Tagle DA, Smith S, Uziel T, Sfez S, et al. (1995) A single ataxia telangiectasia gene with a product similar to PI-3 kinase. Science 268: $1749-1753$

Seki N, Nimura Y, Ohira M, Saito T, Ichimiya S, Nomura N, Nakagawara A (1997) Identification and chromosome assignment of a human gene encoding a novel phosphatidylinositol-3 kinase. DNA Res 4: 355-358

Wu X, Lieber MR (1997) Interaction between DNA-dependent protein kinase and a novel protein, KIP. Mutat Res 385: 13-20 